\title{
Oxidative Stress and Superficial Scald of Apple Fruit
}

\author{
Bruce D. Whitaker ${ }^{1}$ \\ U.S. Department of Agriculture, Agricultural Research Service, Produce Quality and Safety Laboratory, Beltsville \\ Agricultural Research Center, 10300 Baltimore Avenue, Beltsville, MD 20705
}

Superficial scald of apples and pears, which manifests as brown or black patches on the fruit skin, results from necrosis of the hypodermal cortical tissue (Bain and Mercer, 1963) and is thought to be induced by oxidation products of the sesquiterpene $(E, E)$ - $\alpha$-farnesene (Anet, 1972a; Huelin and Coggiola, 1970a, 1970b; Huelin and Murray, 1966). Synthesis of sesquiterpenes in plant tissues occurs mainly via the cytosolic mevalonic acid (MVA) pathway, which is initiated by the enzyme 3-hydroxy-3-methylglutaryl-CoA reductase (HMGR) (Eisenreich et al., 2001). Studies utilizing radiolabeled precursors (Rupasinghe et al., 2001) or a statin inhibitor of HMGR (Ju and Curry, 2000a) indicated that in apple peel $\alpha$-farnesene is synthesized almost exclusively via the MVA pathway, rather than the chloroplastic deoxyxylulose phosphate pathway. Fruit of scald-susceptible apple cultivars such as 'Granny Smith', 'Law Rome', and 'Red Delicious' typically exhibit a burst of $\alpha$-farnesene synthesis shortly after they are placed in low-temperature storage, which results in a marked accumulation of the sesquiterpene in the skin and epicuticular coating during the first 8 to 12 weeks (Fig. 1a) (Anet, 1972a; Huelin and Coggiola, 1968; Whitaker et al., 1997, 1998). The concentration of $\alpha$-farnesene subsequently plateaus and then declines as its conjugated triene oxidation products increase to a maximum at $\approx 20$ to 28 weeks (Fig. 1b) (Anet, 1972a; Huelin and Coggiola, 1970a; Whitaker et al., 1997, 1998).

The primary in vivo oxidation products of $\alpha$-farnesene that accumulate in apple epicuticular wax and peel tissue during cold storage have been identified as conjugated trienols, $9 E$ and $9 Z$ isomers of 2,6,10-trimethyldodeca-2,7,9,11-tetraen-6-ol (Rowan et al., 1995; Whitaker et al., 1997). A recent study showed that application of these conjugated trienols and their corresponding hydroperoxides to apple fruit before storage induced symptoms indistinguishable from naturally occurring superficial scald (Rowan et al., 2001). Prestorage treatment of apples with the antioxidant diphenylamine (DPA) inhibits oxidation of $\alpha$-farnesene and largely prevents development of scald (Huelin and Coggiola, 1970a). Moreover, exposure of apple fruit to the blockers of ethylene action diazocyclopentadiene and 1-methylcyclopropene (1-MCP) greatly curtails $\alpha$-farnesene production and markedly reduces scald incidence and severity (Gong and Tian, 1998; Fan et al., 1999; Rupasinghe et al., 2000a; Shaham et al., 2003; Watkins et al., 2000). Results from the studies with 1-MCP as well as several previous reports (Du and Bramlage, 1994a; Watkins et al., 1993, 1995; Whitaker and Solomos, 1997) show that ethylene perception, production, and responsiveness are clearly involved in regulation of $\alpha$-farnesene synthesis and induction of scald in apple fruit.

This paper presents and overview of $\alpha$-farnesene biosynthesis and oxidation in apple fruit in relation to the longstanding hypothesis that oxidation products of this sesquiterpene are directly involved in induction of superficial scald. Progress toward understanding regulation of $\alpha$-farnesene synthesis in apple by specific genes and enzymes is reviewed, and strategies for molecular genetic suppression of $\alpha$-farnesene synthesis are discussed. In addition, an alternative hypothesis that apple scald is caused by more general oxidative stress and the inability to detoxify reactive oxygen species and free radicals is briefly elaborated.

\footnotetext{
Received for publication 2 Feb. 2004. Accepted for publication 2 Feb. 2004. I thank Steven W. Pechous and Karen C. Green for their invaluable technical assistance in conducting the molecular biology experiments reported in this paper. I also thank Christopher B. Watkins and Jacqueline F. Nock at Cornell Univ. for performing the 1-MCP treatments and providing the peel tissue from 'Law Rome' apple fruit that was used in our molecular biology studies. Mention of a trademark, proprietary product, or vendor does not constitute a guarantee or warranty of the product by the U.S. Dept. of Agriculture and does not imply its approval to the exclusion of other products or vendors that also may be suitable.
}

${ }^{1}$ To whom reprint requests should be addressed; e-mail whitakeb@ba.ars.usda.gov.

\section{OXIDATION PRODUCTS OF $\alpha$-FARNESENE}

It was first proposed that oxidation products of $\alpha$-farnesene are the causal agents of superficial scald in reports by Huelin and Murray (1966) and Huelin and Coggiola (1968). Anet (1969) isolated $\alpha$-farnesene from apples and characterized the products of its in vitro autoxidation. The principal oxidation products were identified as $7 E, 9 E$ and $7 E, 9 Z$ isomers of a farnesyl 6-hydroperoxide (Fig. 2a and b, respectively) and mixed diastereoisomers of a farnesyl endoperoxy-hydroperoxide (Fig. 2c), all of which had UV spectra with a series of absorbance maxima at 259, 269, and $281 \mathrm{~nm}$, reflecting the presence of three conjugated double bonds in the structure. As a group these compounds were called conjugated trienes (CTs), and in a concurrent study by Huelin and Coggiola (1970a) it was shown that oxidation of $\alpha$-farnesene to CTs was inhibited by the antioxidant DPA both in vitro (in hexane solution) and in vivo (in the epicuticular coating of apple fruit).

On the basis of these findings, it was long assumed that the CTs that accumulated on the surface of apples as a consequence of $\alpha$-farnesene oxidation during low-temperature storage were identical to those produced during in vitro autoxidation of $\alpha$-farnesene. However, Rowan et al. (1995) determined that $\approx 96 \%$ to $99 \%$ of the CTs in hexane-dip extracts of cold-stored 'Granny Smith' fruit were conjugated trienols, the 7E,9E

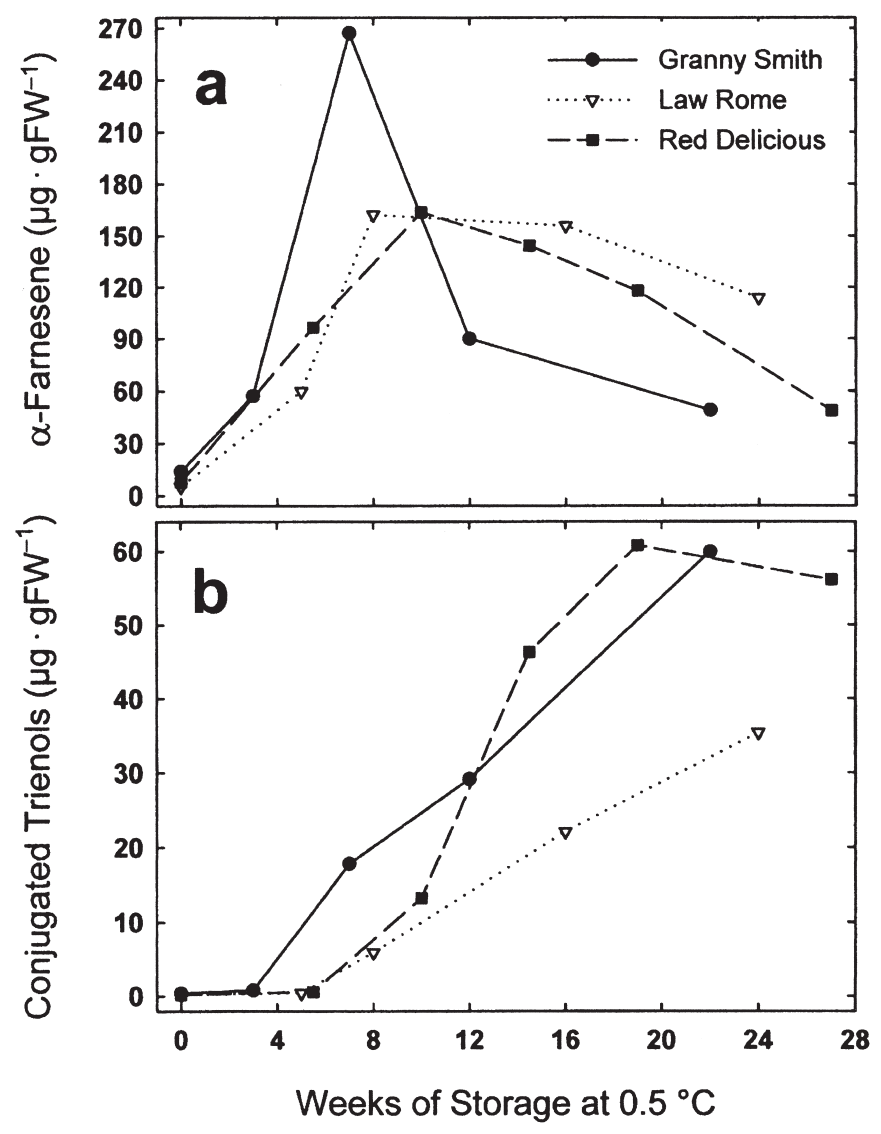

Fig. 1. Accumulation of $\alpha$-farnesene (a) and its conjugated trienol oxidation products (b) on the surface of scald-susceptible 'Granny Smith', 'Law Rome', and 'Red Delicious' apples stored in air at $0.5^{\circ} \mathrm{C}$ for up to 28 weeks. Peel tissue samples were extracted with hexane and aliquots of the hexane extracts were analyzed by high-performance liquid chromatography with UV detection at 232 and $269 \mathrm{~nm}$. 

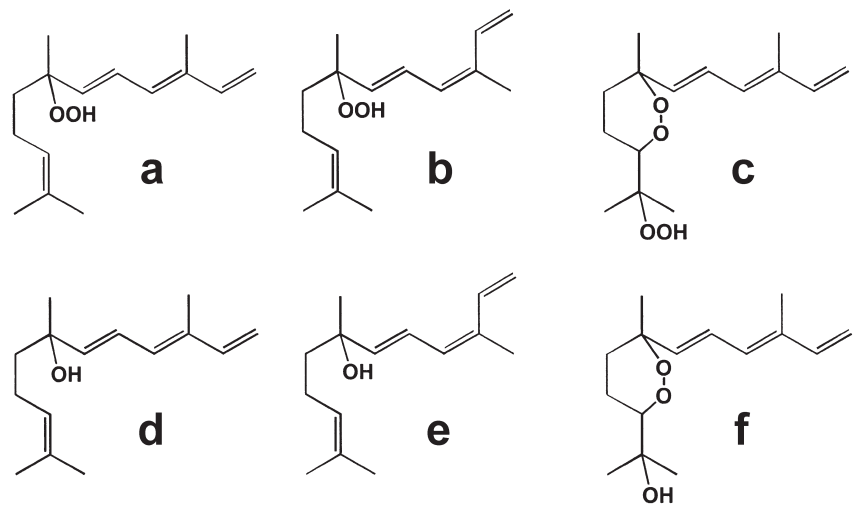

Fig. 2. Primary hydroperoxide (a and b) and endoperoxy-hydroperoxide (c) conjugated triene autoxidation products of $\alpha$-farnesene and their corresponding conjugated trienol reduction products $\mathbf{d}, \mathbf{e}$, and $\mathbf{f}$, respectively. During cold storage, the $7 E, 9 E$ and $7 E, 9 Z$ conjugated trienol isomers $\mathbf{d}$ and $\mathbf{e}$, respectively, accumulate on the surface of scald-susceptible apples, whereas the endoperoxy-alcohol f does not. It is currently not known whether reduction of $\mathbf{a}$ and $\mathbf{b}$ to $\mathbf{d}$ and $\mathbf{e}$ in vivo is enzymatic or nonenzymatic.

and $7 E, 9 Z$ isomers of 2,6,10-trimethyl-2,7,9,11-dodecatetraene-6-ol (Fig. $2 \mathrm{~d}$ and e, respectively), present in a ratio of $\approx 9: 1$. Analysis of extracts from cold-stored 'Delicious' apples in my laboratory corroborated this discovery, and again the ratio of the $7 E, 9 E$ isomer $d$ to the $7 E, 9 Z$ isomer e was $\approx 9: 1$ (Whitaker et al., 1997). These conjugated trienol isomers were obtained in about the same ratio when Anet (1969) used sodium borohydride to reduce, and thereby stabilize, the corresponding 6-hydroperoxides $\mathrm{a}$ and $\mathrm{b}$ that were present in a thin-layer chromatography fraction of the $\alpha$-farnesene autoxidation products. This raises the intriguing question of how the conjugated trienols arise in the skin and epicuticular wax of apple fruit. Rowan et al. (1995) observed that as the 6-hydroperoxide a slowly decomposed in pentane at $-20{ }^{\circ} \mathrm{C}, \approx 10 \%$ was converted to the trienol d. Perhaps this conversion is more efficient at 0 ${ }^{\circ} \mathrm{C}$ in the waxy matrix on the surface of apple fruit. Another explanation is that the 6-hydroperoxide isomers a and $b$ are enzymatically reduced to the corresponding alcohols $\mathrm{d}$ and e by a peroxidase that acts on alkyl hydroperoxide substrates. A lipid hydroperoxide-dependent glutathione peroxidase encoded by a gene that is upregulated in response to active oxygen species (AOS) in senescing leaves (Navabour et al., 2003) might be an example of such an enzyme in plant tissues. Another related question is why do the conjugated trienols often accumulate to high levels in apple fruit, whereas isomers of the endoperoxy-alcohol (Fig. 2f), derived by reduction of the endoperoxy-hydroperoxide autoxidation product $\mathrm{c}$, do not accumulate. This may be due to both the extreme instability of the endoperoxy-hydroperoxide $\mathrm{c}$ and its limited production, which occurs via further oxidation of the 6-hydroperoxide a (Anet, 1969; Rowan et al., 1995, 2001). In addition, if reduction of the peroxides to alcohols is enzymatic, c may be a poor substrate compared with a and b.

Early research on scald indicated a key role of toxic volatiles (Brooks et al., 1919). In the 1950s and 1960s, several groups examined the correlation of naturally occurring apple volatiles with development of the disorder but failed to identify a likely causal agent (Meigh, 1970). Anet (1972b) subsequently determined that the volatile ketone 6-methyl-5-hepten-2one (MHO) is a major secondary product of $\alpha$-farnesene autoxidation and proposed that it is formed via decomposition of a 6-alkoxy radical intermediate derived from the primary autoxidation products $\mathrm{a}, \mathrm{b}$, and $\mathrm{c}$. He concluded that the levels of MHO produced in vivo were probably too low to have a toxic effect and suggested that cell damage was most likely caused by free radicals generated during the reaction that yields MHO. However, more recently there has been a resurgence of the hypothesis that MHO does in fact induce scald (Mir et al., 1999; Wang and Dilley, 2000a, 2000b). Mir et al. (1999) observed that 'Cortland' apples released a burst of MHO upon removal from storage, coincident with a marked intensification of scald symptoms, and Wang and Dilley (2000b) reported that MHO production and accumulation showed a strong positive relationship to the scald index in 'Granny Smith' fruit. In contrast, Rupasinghe et al. (2000b) found no correlation between MHO concentrations and scald severity in 'Red Delicious' apples. Moreover, Rowan et al. (2001) did not observe an increase in scald development in apples treated with
MHO. They did, however, suggest that production of MHO by the fruit is likely to be a sensitive indicator of oxidative processes leading to scald. Not surprisingly, MHO is released during in vitro autoxidation of both the CT hydroperoxides a and b (Fielder et al., 1998) and the conjugated trienols d ande (Whitaker and Saftner, 2000). Kinetics of the autoxidation of $\mathrm{d}$ and e that yielded $\mathrm{MHO}$ were indicative of a free radical-mediated reaction, which was much more rapid at 20 than at $0{ }^{\circ} \mathrm{C}$.

\section{ROLE OF SYNTHETIC AND NATURAL ANTIOXIDANTS}

The efficacy of DPA treatment as a means of scald control was discovered by Smock (1955), and Huelin (1964) determined that several related amino compounds, including dibenzylamine, dicyclohexylamine, and $\mathrm{N}$-benzylaniline, were also effective. As mentioned previously, Huelin and Coggiola (1970a) showed that DPA inhibited autoxidation of $\alpha$-farnesene to CTs both in vitro and in vivo. Anet and Coggiola (1974) subsequently evaluated the ability of a variety of lipophilic antioxidants to control $\alpha$-farnesene autoxidation. They found that all classes of antioxidants tested were capable of inhibiting autoxidation of the sesquiterpene in vitro, whereas only DPA and related amine-type compounds effectively blocked the accumulation of CTs in vivo. These results prompted investigation of possible modes of action of DPA in scald prevention other than inhibition of $\alpha$-farnesene autoxidation. Several studies showed a reduction or delay in $\alpha$-farnesene production in DPA-treated fruit (Du and Bramlage, 1993, 1994a; Huelin and Coggiola, 1968; Whitaker, 2000), but this was not consistently observed (Huelin and Coggiola, 1970b; Lurie et al., 1989). There were also reports of effects of DPA on fruit physiology, including reduced rates of respiration, ethylene production, and senescence (Du and Bramlage, 1994a; Lurie et al., 1989; Whitaker, 2000). These effects are not necessarily persistent, since respiration and ethylene evolution were the same in control and DPA-treated 'Cortland' apples removed from storage after six months (Mir and Beaudry, 1999). Recent evidence indicates that DPA reduces respiration in plant cells by inhibiting mitochondrial electron transport (Purvis and Gegogeine, 2003). It would be interesting to know if related amine-type antioxidants that also prevent scald, such as $N$-isopropyl- $N$ ' phenyl-p-phenylenediamine (Anet and Coggiola, 1974), have a similar effect on plant mitochondria.

Not long after it was proposed that autoxidation products of $\alpha$-farnesene are involved in scald development, the hypothesis was modified to include a role of endogenous antioxidants in delaying the accumulation of CTs, particularly in late-harvest and scald-resistant fruit (Anet, 1972a; Huelin and Coggiola, 1970a, 1970b; Meigh andFilmer, 1969). Anet(1974) isolated 11 lipophilic antioxidants in hexane-dip extracts of apple fruit from 16 cultivars. In general, he observed that a substantial decline in these antioxidants was correlated with the onset of $\alpha$-farnesene autoxidation and the eventual development of scald. Three of the unidentified antioxidant compounds had a pair of UV absorbance maxima ranging from 204 to $207 \mathrm{~nm}$ and 256 to $263 \mathrm{~nm}$, which resembled UV spectra of $p$-hydroxybenzoic acids and esters. Huelin and Coggiola (1970a) had previously found a correlation between 258-nm absorbance in hexane-dip extracts and a low incidence of scald in 'Crofton' and late-pick 'Granny Smith' apples, and more recently Du and Bramlage (1993, 1994a) reported similar findings for 'Cortland' and 'Delicious' apple fruit. Detection of a broad, prominent UV maximum at $258 \mathrm{~nm}$ in hexane extracts of peel tissue from scald-resistant 'Gala' apples prompted me to isolate the compounds responsible for this UV absorbance (Whitaker, 1998). They were identified as a family of mainly saturated, long-chain fattyacid esters of $E$ - and Z-p-coumaryl alcohol, shown in Fig. 3 (Whitaker et al., 2001), and on the basis of their UV spectra, it appears likely that Anet's three unidentified antioxidant compounds belonged to this group. Although these phenolic fatty-acid esters were quite abundant in scaldresistant 'Gala' and were found to have antioxidant activity, they were undetectable in the epicuticular wax of equally scald-resistant 'Empire' fruit (Whitaker, 1998). Thus, these lipophilic antioxidant compounds may help to prevent scald in fruit of some cultivars but they are not universally involved in scald resistance. A variety of antioxidant compounds may serve to delay the onset of $\alpha$-farnesene autoxidation and to generally prevent the accumulation of free radicals and reactive oxygen species (Anet, 1974; Barden and Bramlage, 1994; Gallerani et al., 1990; Meir and Bramlage, 1988). 


\section{GENES AND ENZYMES INVOLVED IN A-FARNESENE SYNTHESIS}

Synthesis of the acyclic sesquiterpene $(E, E)$ - $\alpha$-farnesene in apple peel tissue occurs mainly via the cytosolic MVA pathway (Ju and Curry, 2000a; Rupasinghe et al., 2001), as depicted in the simplified schematic in Fig. 4. Before the first committed step of the pathway, the conversion of HMG-CoA to MVA by HMGR (Fig. 4, step 1), three acetyl-CoA molecules are condensed to yield HMG-CoA. Because the pool of acetyl-CoA increases substantially with the advent of the respiratory climacteric in apple fruit, availability of this substrate may partly determine the rate of $\alpha$-farnesene production during the initial 4 to 8 weeks of storage (Rupasinghe et al., 2001). Ju and Curry (2000a) found that dip treatment of whole apples with the potent HMGR inhibitor lovastatin all but eliminated $\alpha$-farnesene production. They also reported evidence that ethylene-induced transcription and translation of HMGR gene(s) is required for $\alpha$-farnesene synthesis in peel tissue of apple fruit $\mathrm{Ju}$ and Curry, 2000b). On the basis of these reports, and the commonly ascribed role of HMGR as the rate-limiting enzyme in isoprenoid synthesis via the MVA pathway (Goldstein and Brown, 1990; Hartmann et al., 2000), HMGR is considered to be a likely control point in $\alpha$-farnesene production in apple fruit.

In plants, HMGR is typically encoded by small families of genes, designated as $H M G 1, H M G 2, H M G 3$, etc., with a high degree of sequence homology among the cDNA coding regions (McCaskill and Croteau, 1997). Expression of different HMGR genes and isoforms is subject to diverse modes of regulation; expression of a given gene may be constitutive, tissue-specific, or inducible by hormones, infection, or wounding (McCaskill and Croteau, 1997; Piironen et al., 2000). Since ethylene clearly plays a key role in the stimulation of $\alpha$-farnesene production in harvested apples ( Fan et al., 1999; Gong and Tian, 1998; Rupasinghe et al., 2000a; Shaham et al., 2003; Watkins et al., 2000), it is probable that expression of an HMGR gene specifically involved in $\alpha$-farnesene synthesis would be strongly induced by ethylene.

Current research is aimed at identification of an ethylene-inducible HMGR gene in apple peel tissue that could be selectively suppressed to reduce $\alpha$-farnesene synthesis. Complete or partial cDNAs encoding three HMGR isoforms (HMG1, HMG2, and HMG3) have been cloned from commercial apple cultivars. A full-length cDNA of $H M G 1$ has been obtained from 'Delicious', 'Granny Smith', and 'Law Rome' apples (GenBank accession numbers AF315713, AY039230, and AY043490, respectively). Because this isogene is abundantly expressed at harvest and through the first 8 to 16 weeks of storage in both untreated and 1MCP-treated fruit (Rupasinghe et al., 2001; Pechous and Whitaker, 2002), it is unlikely to play a specific role in $\alpha$-farnesene synthesis. The very low level of HMG3 (AY043491) transcript in 'Law Rome' fruit during the interval of maximum $\alpha$-farnesene synthesis suggests that it is also not involved (Pechous and Whitaker, 2002). In contrast, the pattern of expression of HMG2 in 'Delicious' peel tissue (AF316112) was wholly consistent with a role in the postharvest burst of $\alpha$-farnesene production (Rupasinghe et al., 2001). In untreated controls HMG2 transcript increased sharply over the first 8 weeks of storage then declined, whereas in 1-MCP-treated fruit it was nearly absent. We have recently cloned a full-length cDNA of $H M G 2$ from 'Law Rome' and are presently trying to corroborate the findings of Rupasinghe et al. (2001).

HMGR initiates the MVA pathway and thus potentially contributes to the synthesis of a wide variety of isoprenoids. It is logical, therefore, to also clone genes encoding enzymes that catalyze late steps in the $\alpha$-farnesene biosynthetic pathway, with the expectation that their suppression would more specifically inhibit production of the sesquiterpene. Farnesyl diphosphate (FDP) synthase performs the penultimate reaction in the pathway, condensation of geranyl diphosphate and isopentenyl diphosphate to yield FDP (Fig. 4, step 2). A complete cDNA of apple FDP synthase has been cloned from peel tissue of 'Granny Smith' fruit (GenBankaccession number AY083165). Experiments comparing expression of this gene in untreated and 1-MCP-treated 'Granny Smith' apples indicated that it is not upregulated in response to ethylene (T. Solomos, personal communication). In addition, although FDP is the immediate precursor of sesquiterpenes and $\alpha$-farnesene is the predominant sesquiterpene produced in stored apple fruit (Huelin and Murray, 1966; Meigh and Filmer, 1969), FDP is also used in the synthesis of triterpenoids such

as phytosterols. When these facts are considered, it is apparent that the FDP synthase gene probably does not play a primary role in regulation of the $\alpha$-farnesene biosynthetic pathway.

In contrast, $\alpha$-farnesene synthase ( $\alpha$-FS) catalyzes the final step in production of $\alpha$-farnesene (Fig. 4, step 3 ) and consequently this enzyme is the optimal target for specific inhibition of $\alpha$-farnesene synthesis. Rupasinghe et al. (1998) demonstrated the presence of $\alpha$-FS in peel tissue of 'Delicious' apples and identified the substrate as FDP. In a subsequent study, they partially purified and biochemically characterized the enzyme, but were unable to purify the protein to homogeneity due to loss of activity

$$
\text { E-p-Coumaryl }
$$<smiles>O=CC=Cc1ccc(O)cc1</smiles>

\section{$\mathbf{R}=\mathrm{CO}\left(\mathrm{CH}_{2}\right)_{n} \mathrm{CH}_{3} \quad[\mathrm{n}=14-24]$}

Fig. 3. Structures of the long-chain saturated fatty-acid esters of E-p-coumaryl and Z-p-coumaryl alcohol that are abundant in the epicuticular wax of scaldresistant 'Gala' apples and were found to have antioxidant activity.

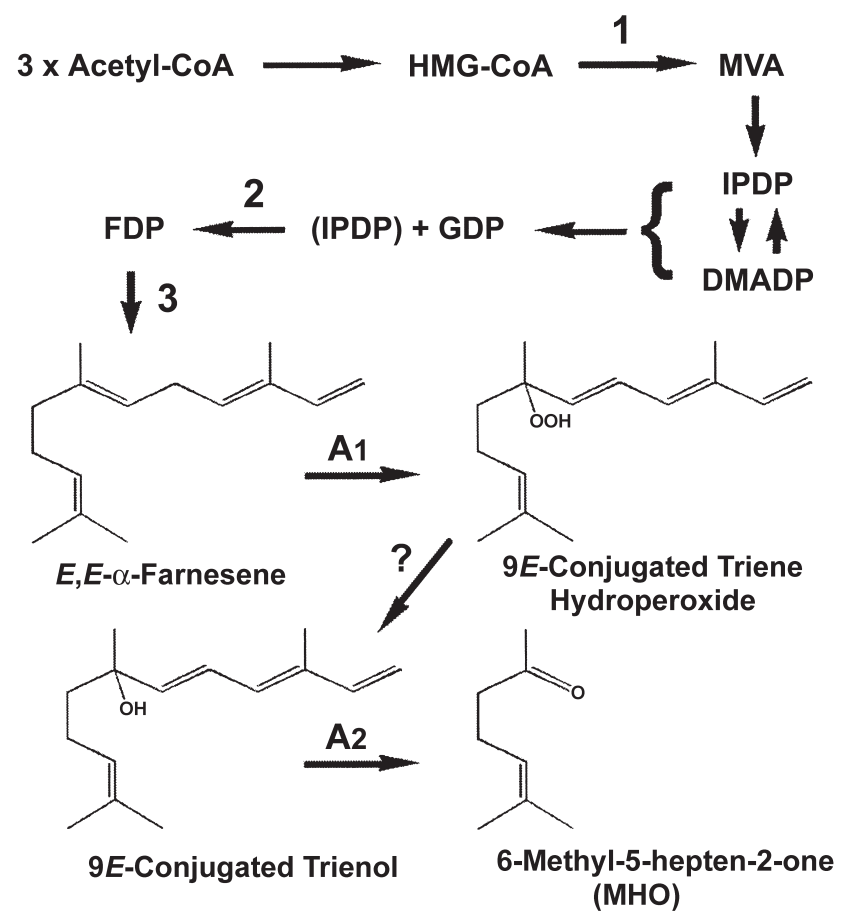

Fig. 4. Simplified schematic of the pathway of $(E, E)$ - $\alpha$-farnesene synthesis and oxidation in apple fruit. Genes have been cloned encoding enzymes that perform steps 1,2, and 3, which are hydroxymethylglutaryl-CoA reductase, farnesyl diphosphate synthase, and $(E, E)$ - $\alpha$-farnesene synthase, respectively. Steps $\mathrm{A} 1$ and $\mathrm{A} 2$, respectively, represent autoxidation of $(E, E)$ - $\alpha$-farnesene to the $7 E, 9 E$ conjugated triene 6-hydroperoxide and autoxidation of the $7 E, 9 E$ conjugated trienol to yield MHO. The step labelled ? indicates the hypothetical enzymatic reduction of the major autoxidation product of $\alpha$-farnesene, the $7 E, 9 E$ conjugated triene 6-hydroperoxide, to the corresponding conjugated trienol. Abbreviations: HMG-CoA, 3-hydroxy-3-methylglutaryl-coenzyme A MVA, mevalonic acid; IPDP, isopentenyl diphosphate; DMADP, dimethylally diphosphate; GDP, geranyl diphosphate; and FDP, farnesyl diphosphate. 
(Rupasinghe et al., 2000b). Moreover, in vitro assays of activity in apple tissue extracts were confounded by competing pyrophosphatase(s) that converted much of the FDP substrate to farnesol. In light of these difficulties, my laboratory chose to undertake cloning and characterization of the $\alpha$-FS gene from peel tissue of scald-susceptible 'Law Rome' apples. We were successful in obtaining a full-length cDNA, AFS1 (AY182241), and quite recently achieved functional expression of the enzyme, which synthesized $(E, E)$ - $\alpha$-farnesene almost exclusively (Pechous and Whitaker, 2004). Rupasinghe et al. (2000b) did not detect an increase in $\alpha$-FS activity in 'Delicious' apples during the first few weeks of storage and saw no effect of 1-MCP treatment. These results are seemingly at odds with our Northern blot and RT-PCR analyses using 'Law Rome' peel tissue RNA, which showed over a twofold increase in AFS1 expression in control fruit and nearly total disappearance of AFS1 transcript in 1MCP-treated fruit (Pechous and Whitaker, 2004). As mentioned above, assays of $\alpha$-FS activity in apple peel tissue extracts are evidently subject to technical problems, so it is hoped that antibodies specific for AFS1 will at least determine if there are changes in $\alpha$-FS enzyme levels over the initial weeks of storage.

Using primers based on the 'Law Rome' AFS1 sequence we were able to rapidly clone the corresponding cDNA from scald-resistant 'Idared' apples. As shown in Fig. 5, a similar percent increase in AFS1 expression occurred in 'Idared' and 'Law Rome' during the first 4 weeks of storage, but AFS1 transcript was consistently about fourfold less abundant in scald-resistant 'Idared' than in scald-susceptible 'Law Rome'. This raises the interesting question of whether the promoters differ for the otherwise nearly identical AFS1 genes from these two cultivars, or perhaps the rate of turnover of AFS1 mRNA differs. Isolation of genomic clones of these genes including the 5'-flanking region will be required to analyze their promoters. For both AFS1 and HMG2, which appear to be upregulated by ethylene, this approach could provide valuable information about ethylene response elements in the promoter region that are involved in the ethylene-induced increase in expression (Deikman, 1997; Solano et al., 1998).

\section{ALTERNATIVE HYPOTHESIS OF SCALD INDUCTION}

There are dissenting views concerning the root cause of apple scald and the genetic basis of scald susceptibility or resistance. A number of researchers have proposed that scald arises as a consequence of more general oxidative stress and that the runaway autoxidation of $\alpha$-farnesene is merely a secondary manifestation of unchecked free radical reactions (Rao et al., 1998; Rupasinghe et al., 2000b). Regardless of the role of $\alpha$-farnesene oxidation products, scald development almost certainly involves the adverse effects of oxidative stress that occurs with prolonged storage at chilling temperatures (Du and Bramlage, 1994b, 1995; Rao et al., 1998; Shewfelt and Purvis, 1995; Watkins et al., 1995). Purvis and Gegogeine (2003) recently proposed that scald arises as a result of superoxide radicals generated by perturbation of the mitochondrial electron transport chain. Several studies have evaluated the accumulation of peroxides and lipid peroxidation products in relation to the activities of enzymes that detoxify AOS in peel tissue of scald-susceptible and -resistant apples. Du and Bramlage (1994b, 1995) found no marked changes in peroxidation or activities of antioxidative enzymes related to scald development in 'Cortland', 'Delicious', and 'Empire'. In marked contrast, Rao et al. (1998) found that in fruit of susceptible and resistant 'White Angel' x 'Rome Beauty' hybrid selections the occurrence and severity of scald were strongly correlated with increasing levels of $\mathrm{H}_{2} \mathrm{O}_{2}$, increasing lipid peroxidation, and decreasing peroxidase and catalase activities. Quite recently, Shaham et al. (2003) compared the activities of five antioxidative enzymes, as well as lipophilic and water-soluble antioxidant capacity, in untreated, heat-treated, and 1-MCP-treated 'Granny Smith' apples. In 1-MCP-treated fruit, the complete prevention of scald was better correlated with antioxidant capacity than with antioxidative enzyme activities, whereas in heat-treated fruit, a substantial delay in scald development was more closely associated with elevated antioxidative enzyme activities.

There are several studies and lines of evidence that challenge the $\alpha$-farnesene oxidation-scald induction hypothesis. Rupasinghe et al. (1998, 2000b) determined that $\alpha$-farnesene synthesis and content were consistently threefold greater in scald-free than in scald-developing apples.

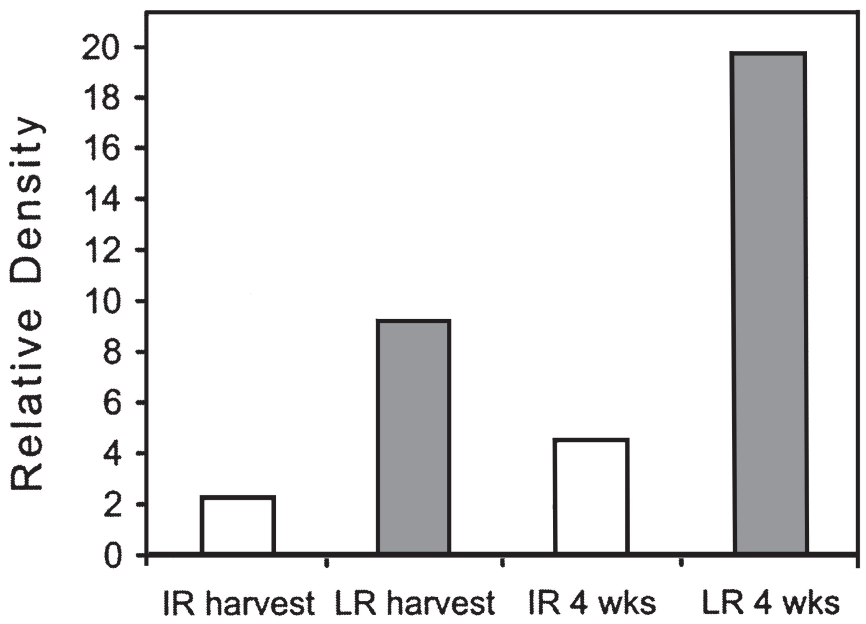

Fig. 5. Relative levels of $(E, E)$ - $\alpha$-farnesene synthase mRNA encoded by the gene AFS1 in peel tissue of scald-resistant 'Idared' (IR) and scald-susceptible 'Law Rome' (LR) apples at harvest and after 4 weeks of storage in air at $0.5^{\circ} \mathrm{C}$. AFS1 transcript levels were determined by reverse transcriptase-polymerase chain reaction amplification and densitometry scanning.

In addition, they found no correlation of $\alpha$-farnesene production, $\alpha$-FS activity, or conjugated trienol accumulation with scald susceptibility in 11 commercial apple cultivars (although scald severity was apparently not evaluated for the fruit used in this study). Rao et al. (1998) also observed that accumulation of $\alpha$-farnesene and CTs was poorly correlated with scald susceptibility among their 'White Angel' $x$ 'Rome Beauty' hybrid selections. In a subsequent investigation with these hybrid lines (Whitaker et al., 2000), it was found that although high levels of $\alpha$-farnesene and conjugated trienols occurred in the lines that scalded severely, there were scald-resistant lines that accumulated equally high levels, and lines that accumulated very low levels yet developed mild to moderate scald. On the basis of these results, it was concluded that oxidation products of $\alpha$-farnesene are not essential for scald development in fruit with severely compromised antioxidative defenses, but free radicals and/or toxic volatiles generated by oxidation of $\alpha$-farnesene can exacerbate scald symptoms.

\section{SUMMARY}

Superficial scald is a costly storage disorder that develops in fruit of susceptible apple cultivars such as 'Granny Smith' and 'Law Rome' after several months at low temperature. Despite intensive investigation, the biochemical mechanism and genetic basis of apple scald remain unknown. Evidence indicates that scald is induced by oxidative stress. The prevailing hypothesis holds that oxidation products of the sesquiterpene $\alpha$-farnesene are directly involved. A dramatic rise in $\alpha$-farnesene synthesis occurs shortly after apples are placed in storage, and oxidation of the accumulated $\alpha$-farnesene proceeds rapidly after $\approx 6$ to 8 weeks, particularly in air-stored fruit. The primary in vitro autoxidation products of $\alpha$-farnesene are conjugated trienes (CTs) composed of several hydroperoxide and endoperoxy-hydroperoxide isomers. However, $>95 \%$ of the CTs that accumulate in the skin of cold-stored apples are two conjugated trienols, $9 E$ and $9 Z$ isomers of 2,6,10-trimethyldodeca-2,7,9,11-tetraen3 -ol, a reduced form of the major hydroperoxide autoxidation products. Application of synthetic CT peroxides or alcohols to apples induces symptoms indistinguishable from superficial scald. Autoxidation of CTs yields the volatile 6-methyl-5-hepten-2-one, which has been implicated as a possible causal agent for scald, but may simply be indicative of damaging free radical-mediated reactions. For the most part, synthesis of $\alpha$-farnesene and accumulation of CTs during apple storage are correlated with the subsequent incidence and severity of scald development. However, exceptions have been noted, where some scald occurs despite low levels of CTs or there is no scald despite moderately high levels of CTs. Further evidence in support of the $\alpha$-farnesene oxidation-scald induction hypothesis was the recent finding that prestorage treatment of scald-susceptible apples with 1-MCP, a blocker of ethylene action, greatly reduced $\alpha$-farnesene synthesis and abolished scald development. 
Yet it can still be argued that ethylene-induced processes other than $\alpha$-farnesene production lead to scald, and it has been proposed that scald results from more general oxidative stress, perhaps triggered by disruption of mitochondrial electron transport at low temperature and the consequent production of superoxide. Molecular genetic disruption of genes controlling $\alpha$-farnesene biosynthesis is a strategy that should prove or disprove the direct role of $\alpha$-farnesene oxidation in the induction of superficial scald. Logical targets for gene knockouts are genes encoding: 1) a sesquiterpene pathway-specific isozyme of 3-hydroxy-3methylglutaryl-CoA reductase (HMGR), and 2) $\alpha$-farnesene synthase, the last enzyme in the pathway that converts FDP to (E,E)- $\alpha$-farnesene. Work is currently in progress to clone and characterize these genes from scald-susceptible and -resistant apple cultivars.

\section{Literature Cited}

Anet, E.F.L.J. 1969. Autoxidation of $\alpha$-farnesene. Austral. J. Chem. 22:2403-2410.

Anet, E.F.L.J. 1972a. Superficial scald, a functional disorder of stored apples. IX. Effect of maturity and ventilation. J. Sci. Food Agr. 23:763-769.

Anet, E.F.L.J. 1972b. Superficial scald, a functional disorder of stored apples. VIII. Volatile products from the autoxidation of $\alpha$-farnesene. J. Sci. Food Agr. 23:605-608.

Anet, E.F.L.J. 1974. Superficial scald, a functional disorder of stored apples. XI. Apple antioxidants. J. Sci. Food Agr. 25:299-304.

Anet, E.F.L.J. and I.M. Coggiola. 1974. Superficial scald, a functional disorder of stored apples. X. Control of $\alpha$-farnesene autoxidation. J. Sci. Food Agr. 25:293-298.

Bain, J.M. and F.J. Mercer. 1963. The submicroscopic cytology of superficial scald, a physiological disease of apples. Austral. J. Biol. Sci. 16:442-449.

Barden, C.L. and W.J. Bramlage. 1994. Relationships of antioxidants in apple peel to changes in $\alpha$-farnesene and conjugated trienes during storage, and to superficial scald developmen after storage. Postharv. Biol. Technol. 4:23-33.

Brooks, C., J.S. Cooley, and D.F. Fisher. 1919. Nature and control of apple scald. J. Agr. Res. 18:211-220.

Deikman, J. 1997. Molecular mechanisms of ethylene regulation of gene transcription. Physiol. Plant. 100:561-566.

Du, Z. and W.J. Bramlage. 1993. A modified hypothesis on the role of conjugated trienes in superficial scald development on stored apples. J. Amer. Soc. Hort Sci. 118:807-813.

Du, Z. and W.J. Bramlage. 1994a. Roles of ethylene in the development of superficial scald in 'Cortland' apples. J. Amer. Soc. Hort Sci. 119:516-523.

Du, Z. and W.J. Bramlage. 1994b. Superoxide dismutase activities in senescing apple fruit (Malus domestica Borkh.). J. Food Sci. 59:581-584.

Du,Z. and W.J. Bramlage. 1995. Peroxidative activity of apple peel in relation to development of poststorage disorders. HortScience 30:205-209.

Eisenreich, W., F. Rohdich, and A. Bacher. 2001. Deoxyxylulose phosphate pathway to terpenoids. Trends Plant Sci. 6:78-84.

Fan, X., J.P. Mattheis, and S. Blankenship. 1999. Development of apple superficial scald, soft scald, core flush, and greasiness is reduced by MCP. J. Agr. Food Chem. 47:3063-3068.

Fielder, S., D.D. Rowan, and M.S. Sherburn. 1998. Synthesis of polyene sesquiterpene hydroperoxides by regio- and stereoselective transposition reactions. Tetrahedron 54:12907-12922.

Gallerani, G., G.C. Pratella, and R.A. Budini. 1990. The distribution and role of natural antioxidant substances in apple fruit affected by superficial scald. Adv. Hort. Sci. 3:144-146

Goldstein, J.L. and M.S. Brown. 1990. Regulation of the mevalonate pathway. Nature 343:425-430.

Gong, Y. and M.S. Tian. 1998. Inhibitory effect of diazocyclopentadiene on the development of superficial scald in Granny Smith apple. Plant Growth Reg. 26:117-121.

Hartmann, M.-A., L. Wentzinger, A. Hemmerlin, and T.J. Bach. 2000. Metabolism of farnesyl diphosphate in tobacco BY-2 cells treated with squalestatin. Biochem. Soc. Trans. 28:794-796.

Huelin, F.E. 1964. Superficial scald, a functional disorder of stored apples. II. Promoters and inhibitors. J. Sci. Food Agr. 15:227-236.

Huelin, F.E. and I.M. Coggiola. 1968. Superficial scald, a functional disorder of stored apples. IV. Effect of variety, maturity, oiled wraps and diphenylamine on scald and the concentration of $\alpha$-farnesene in the fruit. J. Sci. Food Agr. 21:44-48.

Huelin, F.E. and I.M. Coggiola. 1970a. Superficial scald, a functional disorder of stored apples. V. Oxidation of $\alpha$-farnesene and its inhibition by diphenylamine. J. Sci. Food Agr. 21:44-48.

Huelin,F.E. and I.M. Coggiola. 1970b. Superficial scald, a functional disorder of stored apples. VII. Effect of applied $\alpha$-farnesene, temperature and diphenylamine on scald and the concentration and oxidation of $\alpha$-farnesene in the fruit. J. Sci. Food Agr. 21:44-48.

Huelin, F.E. and K.E. Murray. 1966. $\alpha$-Farnesene in the natural coating of apples. Nature 210:1260-1261

Ju, Z. and E. Curry. 2000a. Lovastatin inhibits $\alpha$-farnesene synthesis without affecting ethylene production during fruit ripening in 'Golden Supreme' apples. J. Amer. Soc. Hort. Sci. 125:105-110.

Ju, Z. and E. Curry. 2000b. Evidence that $\alpha$-farnesene biosynthesis during fruit ripening is mediated by ethylene regulated gene expression in apples. Postharv. Biol. Technol. 19:9-16.

Lurie, S., J. Klein, and R. Ben-Arie. 1989. Physiological changes in diphenylamine-treated 'Granny Smith' apples. Israel J. Bot. 38:199-207.

McCaskill,D. and R. Croteau. 1997. Prospects for the bioengineering of isoprenoid biosynthesis. Adv. Biochem. Eng. Biotechnol. 55:107-146.

Meigh, D.F. 1970. Apple scald, p. 555-569. In: A.C. Hulme (ed.). The biochemistry of fruits and their products. Academic Press, London.
Meigh, D.F. and A.A.E. Filmer. 1969. Natural skin coating of the apple and its influence on scald in storage. III. $\alpha$-Farnesene. J. Sci. Food Agr. 20:139-143.

Meir, S. and W.J. Bramlage. 1988. Antioxidant activity in 'Cortland' apple peel and susceptibility to superficial scald after storage. J. Amer. Soc. Hort. Sci. 113:412-418.

Mir N.A. and R. Beadry. 1999. Effect of superficial scald suppression by diphenylamine application on volatile evolution by stored Cortland apple fruit. J. Agr. Food Chem. 47:7-11.

Mir, N.A., R. Perez, and R.M. Beaudry. 1999. A poststorage burst of 6-methyl-5-hepten-2-one (MHO) may be related to superficial scald development in 'Cortland' apples. J. Amer. Soc. Hort. Sci. 124:173-176.

Navabpour, S., K. Morris, R. Allen, E. Harrison, S.A.-H.-Mackerness, and V. Buchanan-Wollaston. 2003. Expression of senescence-enhanced genes in response to oxidative stress J. Expt. Bot. 54:2285-2292.

Pechous S.W. and B.D. Whitaker. 2002. Cloning and bacterial expression of a 3-hydroxy-3 methylglutaryl-CoA reductase cDNA ( $H M G 1)$ from peel tissue of apple fruit. J. Plan Physiol. 159:907-916.

Pechous S.W. and B.D. Whitaker. 2004. Cloning and functional expression of an (E,E)- $\alpha-$ farnesene synthase cDNA from peel tissue of apple fruit. Planta 219:84-94.

Piironen V., D.G. Lindsay, T.A. Miettinen, J. Toivo, and A.-M. Lampi. 2000. Plant sterols: biosynthesis, biological function and their importance to human nutrition. J. Sci. Food Agr. 80:939-966.

Purvis, A.C. and J.W. Gegogeine. 2003. Diphenylamine inhibits respiration of green bell peppers. J. Amer. Soc. Hort. Sci. 128:924-929.

Rao, M.V., C.B. Watkins, S.K. Brown, and N.F. Weeden. 1998. Active oxygen species in 'White Angel' x 'Rome Beauty' apple selections resistant and susceptible to superficial scald. J. Amer. Soc. Hort. Sci. 123:299-304

Rowan D.D., J.M. Allen, S. Fielder, J.A. Spicer, and M.A. Brimble. 1995. Identification of conjugated triene oxidation products of $\alpha$-farnesene in apple skin. J. Agr. Food Chem. 43:2040-2045.

Rowan D.D., M.B. Hunt, S. Fielder, J. Norris, and M.S. Sherburn. 2001. Conjugated triene oxidation products of $\alpha$-farnesene induce symptoms of superficial scald on stored apples. J. Agr. Food Chem. 49:2780-2787.

Rupasinghe H.P.V., K.C. Almquist, G. Paliyath, and D.P. Murr. 2001. Cloning of $h m g l$ and hmg2 cDNAs encoding 3-hydroxy-3-methylglutaryl coenzyme A reductase and their expression and activity in relation to $\alpha$-farnesene synthesis in apple. Plant Physiol Biochem. 39:933-947.

Rupasinghe H.P.V., D.P. Murr, G. Paliyath, and L. Skog. 2000a. Inhibitory effect of 1-MCP on ripening and superficial scald development in 'McIntosh' and 'Delicious' apples. J. Hort. Sci. Biotechnol. 75:271-276.

Rupasinghe H.P.V., G. Paliyath, and D.P. Murr. 1998. Biosynthesis of $\alpha$-farnesene and its relation to superficial scald development in 'Delicious' apples. J. Amer. Soc. Hort. Sci. 123:882-886.

Rupasinghe H.P.V., G. Paliyath, and D.P. Murr. 2000b. Sesquiterpene $\alpha$-farnesene synthase: Partial purification, characterization, and activity in relation to superficial scald development in apples. J. Amer. Soc. Hort. Sci. 125:111-119.

Shaham, Z., A. Lers, and S. Lurie. 2003. Effect of heat or 1-methylcyclopropene on antioxidative enzyme activities and antioxidants in apples in relation to superficial scald development. J. Amer. Soc. Hort. Sci. 128:761-766.

Shewfelt, R.L. and A.C. Purvis. 1995. Toward a comprehensive model for lipid peroxidation in plant tissue disorders. HortScience 30:213-218.

Smock, R.M. 1955. A new method of scald control. Amer. Fruit Grower 75:20.

Solano, R., A. Stepanova, Q. Chao, and J.R. Ecker. 1998. Nuclear events in ethylene signaling: a transcriptional cascade mediated by ETHYLENE-INSENSITIVE3 and ETHYLENERESPONSE-FACTOR1. Genes Dev. 12:3703-3714.

Wang, Z. and D.R. Dilley. 2000a. Hypobaric storage removes scald-related volatiles during the low temperature induction of superficial scald of apples. Postharv. Biol. Technol. 18:191-199.

Wang,Z. and D.R. Dilley. 2000b. Initial low oxygen stress controls superficial scald of apples. Postharv. Biol. Technol. 18:201-213.

Watkins, C.B., C.L. Barden, and W.J. Bramlage. 1993. Relationships among $\alpha$-farnesene conjugated trienes and ethylene production with superficial scald development of apples. Acta Hort. 343:155-160.

Watkins, C.B., W.J. Bramlage, and B.A. Cregoe. 1995. Superficial scald of 'Granny Smith' apples is expressed as a typical chilling injury. J. Amer. Soc. Hort. Sci. 120:88-94.

Watkins, C.B., J.F. Nock, and B.D. Whitaker. 2000. Responses of early, mid and late season apple cultivars to postharvest application of 1-methylcyclopropene (1-MCP) under ai and controlled atmosphere storage conditions. Postharv. Biol. Technol. 19:17-32.

Whitaker, B.D. 1998. Phenolic fatty-acid esters from the peel of 'Gala' apples and their possible role in resistance to superficial scald. Postharv. Biol. Technol. 13:1-10.

Whitaker, B.D. 2000. DPA treatment alters $\alpha$-farnesene metabolism in peel of 'Empire' apples stored in air or $1.5 \%$ O2 atmosphere. Postharv. Biol. Technol. 18:91-97.

Whitaker, B.D. and R.A. Saftner. 2000. Temperature-dependent autoxidation of conjugated trienols from apple peel yields 6-methyl-5-hepten-2-one, a volatile implicated in induction of superficial scald. J. Agr. Food Chem. 48:2040-2043.

Whitaker, B.D. and T. Solomos. 1997. Scald prevention and reduction of $\alpha$-farnesene synthesis and oxidation in 'Granny Smith' and 'Empire' apples. Proc. 7th Intl. Contr. Atm. Res. Conf. 2:91-97.

Whitaker, B.D., J.F. Nock, and C.B. Watkins. 2000. Peel tissue $\alpha$-farnesene and conjugated trienol concentrations during storage of 'White Angel' x 'Rome Beauty' apple selection susceptible and resistant to superficial scald. Postharv. Biol. Technol. 20:231-241.

Whitaker, B.D., W.F. Schmidt, M.C. Kirk, and S. Barnes. 2001. Novel fatty acid esters of p-coumaryl alcohol in epicuticular wax of apple fruit. J. Agr. Food Chem. 49:3787-3792.

Whitaker, B.D., T. Solomos, and D.J. Harrison. 1997. Quantification of $\alpha$-farnesene and its conjugated trienol oxidation products from apple peel by $\mathrm{C}_{18}$-HPLC with UV detection. J. Agr. Food Chem. 45:760-765.

Whitaker, B.D., T. Solomos, and D.J. Harrison. 1998. Synthesis and oxidation of $\alpha$-farnesene during high and low $\mathrm{O}_{2}$ storage of apple cultivars differing in scald susceptibility. Acta Hort. 464:165-171. 